\title{
BALTIJOS GEODEZIJOS KOMISIJOS VEIKLA TARPUKARIU
}

\author{
Minint 80-ąsias Komisijos ịkūrimo metines
}

\author{
Stasys Vytautas Kazakevičius, Arūnas Būga \\ Geodezijos institutas, Vilniaus Gedimino technikos universitetas, Saulètekio al.11, LT-10223 Vilnius-40, Lietuva, \\ el.paštas: gi@takas.lt
}

Iteikta 20031125 , priimta 20040210

\begin{abstract}
Santrauka. 1924 m. buvo numatyta ikurti Baltijos geodezijos komisiją. Ilkurtosios komisijos iniciatyva pradedama sudaryti Baltijos trianguliacijos grandinę. Sudaryta trianguliacijos grandinè aplink Baltijos jūrą leido šalims sujungti trianguliacijos tinklus bei atlikti bendraji trianguliacijos grandinės išlyginimą. Nors Baltijos geodezijos komisijos veiklą nutraukè Antrasis pasaulinis karas, tačiau jos atlikti darbai tebėra aktualūs iki šių dienų.
\end{abstract}

Raktažodžiai: trianguliacijos tinklai, Baltijos geodezijos komisija, Baltijos trianguliacijos grandinė

\section{Ivadas}

Pasibaigus Pirmajam pasauliniam karui keletas nepriklausomomis tapusių valstybių prie Baltijos jūros iš carinès Rusijos imperijos paveldèjo gana prastus geodezinius tinklus. Atkurtose valstybėse, tarp jų ir Lietuvoje, buvo išlikę senuju krašto trianguliacijos ir niveliacijos tinklų fragmentų, kurių menkas tikslumas ir nepatikimos sąsajos neatitiko praktinių reikmių. Neturint pakankamai tikslaus ir vientiso geodezinio pagrindo nebuvo sąlygu sudaryti visaverčius topografinius žemėlapius, labai reikalingus atkuriant karo sugriautą ūki, vykdant žemès reformą, rekonstruojant senuosius kelius bei tiesiant naujus. Organizuoti naujų geodezinių tinklu sudarymą èmési Baltijos geodezijos komisija. Ji subūrè suinteresuotas šalis siekti bendro tikslo - kurti vientisą geodezini pagrindą, nutiesiant trianguliacijos grandinę aplink Baltijos jūrą, vadinamają Baltijos grandinę, ir sudarant bendrą precizinès niveliacijos tinklą.

\section{Baltijos geodezijos komisijos ịkūrimas}

Pirmojo pasaulinio karo pabaigoje iš šalių, išsilaisvinusių iš Rusijos imperijos, geodezinių tinklų sudarymo uždaviniai sèkmingiausiai buvo sprendžiami Suomijoje, - 1918 m. ikurtas Geodezijos institutas. Pirmuoju šio instituto vadovu tapo jo steigejas prof. T. I. Bonsdorfas (Toivo Ilmari Bonsdorff, 1879-1950). Jis nedelsdamas èmèsi naujo Suomijos trianguliacijos tinklo sudarymo. Sèkmingai pradèjęs trianguliacijos darbus savoje šalyje, prof. T. I. Bons-dorfas ragino organizuoti bendrus pagrindinius geodezinius darbus visose Baltijos jūrą supančiose šalyse. Pritarusi tokiai iniciatyvai, Suomijos vyriausybė 19230430 raštu kreipèsi i Danijos, Estijos, Latvijos, Lenkijos, Lietuvos, Švedijos ir Vokietijos vyriausybes, kviesdama atsiųsti savo atstovus į Suomijoje rengiamą konferenciją bendruju geodezinių tinklų sudarymo klausimais. Konferencija ivvyko 1924 m. biržely Helsinkyje. Dalyvavo Suomijos ir visų minètų šalių, išskyrus Daniją, atstovai.

Helsinkio konferencijoje buvo ivertinti atstovaujamu šalių trianguliacijos tinklai ir jų sujungimo i bendrą grandinę, juosiančią Baltijos jūrą, galimybès. Išryškèjo labai nevienodos sąlygos, susiklosčiusios skirtingose šalyse, tačiau buvo susitarta ne tik dèl Baltijos trianguliacijos grandinès principinès schemos, bet ir dèl jos realizavimo būdo. Helsinkio konferencijoje buvo apsvarstyta naujų trianguliacijos tinklų sudarymo atstovaujamose šalyse technologija, susitarta dèl trikampių formos ir kraštinių ilgio. Aptarti reikalavimai, kelti kampu matavimo prietaisams, priimta kampu matavimo metodika ir numatytos rezultatu tikslumo normos. Buvo priimtas nutarimas dèl bazių išdèstymo Baltijos trianguliacijos grandinèje, jų matavimo prietaisų komparavimo sekos ir rekomenduojamos bazès tinklo formos. Konferencijoje nutarta išmatuoti keletą Baltijos grandinès bazių, tarp jų vieną Lietuvos teritorijoje. Aptartas Laplaso punktu trianguliacijos tinkluose tankumas ir astronominiu matavimu šiuose punktuose metodika bei tikslumas. Trianguliacijos tinklams redukuoti i elipsoidą numatyti gravimetriniai matavimai. Ateities darbų programoje, Lietuvos delegacijos vadovui prof. S. Kolupailai pasiūlius, numatyta sudaryti Baltijos jūrą juosiantị precizinès niveliacijos žiedą. Estijos delegacijos iniciatyva numatyti magnetometriniai matavimai dalyvaujančių šalių teritorijose ir Baltijos jūros bei Suomijos ilankos akvatorijoje [1].

Helsinkio konferencijos nutarimai tapo bendru darbu programos pagrindu. Jais vadovautasi be didesniu pakeitimu ir papildymų daugeli metų. Pažymètina, kad šioje konferencijoje buvo išspręsti svarbiausi organizaciniai klausimai, todèl vèliau ikurtoji Baltijos geodezijos komisija galèjo rūpintis beveik išimtinai tik techniniais ir moksliniais klausimais [2]. 1924 m. Helsinkio konferencijos delegatai isipareigojo pasiūlyti savo šalių vyriausybèms toki nutarimą: 
Konferencijoje atstovautosios valstybès susivienija, kad galètu atlikti bendrus geodezinius ir geodezines astronomijos darbus aplink Baltijos jūrq. Šiu valstybiu vyriausybès paskiria po viena igaliotaji nari su sprendžiamuoju balsu, esant reikalui - ir kitus kompetentingus narius, turinčius patariamaji balsq. Nariu visuma sudaro Baltijos geodezijos komisija. Jos uždavinys - prižiūrèti matavimu eigq. Komisija kas metai renkasi posédžiauti. Reikalus tvarko komisijos prezidentas, viceprezidentas ir generalinis sekretorius.

Kitoms šalims, norinčioms dalyvauti bendruose darbuose, paliekama galimybe istoti $i$ Baltijos Geodezijos komisija.

Remiantis Helsinkio konferencijos nutarimais, 1924 m. rudeni Suomijos vyriausybè kreipèsi i Baltijos jūros valstybių vyriausybes su pasiūlymu sudaryti tarpvalstybini susitarimą dèl Baltijos geodezijos komisijos ikūrimo ir išlaikymo. Siūlomo susitarimo, pavadinto Baltijos geodezijos konvencija, preambulèje nurodyta, kad Vokietija, Danija, Laisvasis Dancigo miestas, Estija, Suomija, Latvija, Lietuva, Lenkija ir Švedija nutaria dvylikos metų laikotarpiui ikurti Baltijos geodezijos komisiją. Konvencijos tekste pabrèžtas pagrindinis Baltijos geodezijos komisijos uždavinys: siekti, kad Baltijos jūrą supančiose šalyse atliekami geodeziniai darbai - pirmosios eilès trianguliacija, baziu matavimai, astronominiu koordinačių nustatymas bei sunkio matavimai - būtų daromi vienodais pagrindais ir metodais, o gaunami rezultatai tenkintu visas praktikos ir mokslo reikmes. Konvencijoje pažymėta, kad kiekviena valstybè skiria $\mathfrak{i}$ Komisiją po vieną nari, turinti spriandžiamaji balsą, ir neribotą skaičių narių, turinčių patariamaji balsą. Taip užtikrinamos lygios visų dalyvaujančių šalių teisès, nepriklausomai nuo jų dydžio. Komisijos veiklos klausimus numatyta spręsti balsų dauguma kasmet vykstančiuose suvažiavimuose. Konvencijoje pažymètas ipareigojimas kiekvienos valstybès teritorijoje matavimus atlikti savomis jègomis ir lěšomis, o gautus rezultatus skelbti leidiniuose arba tiesiogiai pateikti Komisijai. Konvencijoje numatyta, jog bendrosioms Baltijos geodezijos komisijos išlaidoms padengti didžiosios valstybès - Suomija, Švedija ir Vokietija įsipareigoja kasmet imokèti po 500 JAV doleriu, o kitos valstybès, tarp jų ir Lietuva, - po 250 dolerių. Lèšos panaudojamos bendriems matavimų darbams finansuoti, spaudos išlaidoms padengti ir Komisijos generaliniam sekretoriui išlaikyti [3].

Visos Baltijos jūrą supančios valstybès iki 1925 m. pabaigos pareiškè pritariančios konvencijai. Ji buvo ratifikuota. Lietuvos Respublikos Seimas konvenciją ratifikavo 1926 m. lapkričio 16 d. [4]. Konvencija įsigaliojo 12 metų laikotarpiui, skaičiuojant nuo 1925 m. pradžios.

\section{Baltijos geodezijos komisijos veikla}

Ikūrus Baltijos geodezijos komisiją, $1926 \mathrm{~m}$. rugpjūty Stokholme izvyko antrasis atstovaujamų šalių delegacijų susitikimas, pavadintas suvažiavimu, kuriame dalyvavo visų minètų aštuonių valstybių ir Laisvojo Dancigo (Gdansko) miesto atstovai. Pastarojo miesto atstovai drauge su Lenkijos delegacija turejo tik vieno balso teisę. Stokholmo suvažiavime buvo išklausyti dalyvaujančių šalių pranešimai. Iš jų aiškèjo, kad Baltijos trianguliacijos grandinès sudarymo darbai pradeti dar ne visose šalyse. Lietuvai atstovavęs prof. S. Kolupaila savo pranešime pažymèjo, kad šalyje vos tik pradèta rengtis trianguliacijos darbams. Dèl to suvažiavime net mèginta ieškoti būdų, kaip nutiesti Baltijos trianguliacijos grandinę aplenkiant Lietuvą [5]. Stokholmo suvažiavimas prièmè keletą nutarimu, susijusių su Baltijos trianguliacijos grandinès sudarymu. Svarbiausieji iš jų:

- dèl Baltijos trianguliacijos grandinès bazių matavimo naudojant tuos pačius prietaisus ir dirbant tiems patiems matuotojams;

- dèl tinkamiausio išmatuotos Baltijos trianguliacijos grandinès išlyginimo metodo parinkimo;

- dèl nepriklausomo trianguliacijos trikampių, kertančių valstybių sienas, kampu matavimo abiejų kaimyninių šalių jègomis;

- dèl pagrindiniu astronominiu stočių ilgumų nustatymo dalyvaujančiose valstybėse;

- dèl sunkio jègos matavimo pagrindiniuose valstybiu punktuose.

Siekiant tinkamai igyvendunti Stokholmo suvažiavimo nutarimus, sudarytos keturios komisijos: bazių matavimo, Baltijos trianguliacijos grandinès išlyginimo, astronominiu ilgumų nustatymo ir sunkio jègos matavimo [3].

Trečiajame Baltijos geodezijos komisijos suvažiavime, kuris ivvyko 1927 m. gegužę Rygoje, buvo apsvarstyta informacija apie trianguliacijos darbus, pradètus Estijoje, Latvijoje ir Lietuvoje. Lietuvos delegacijos vadovas prof. S. Kolupaila pateikè trianguliacijos grandinès, jungiančios Rytu Prūsijos ir Latvijos tinklus, bei parinktos vietos Švèkšnos bazei ir šios bazès tinklo projektus. Buvo išklausyti specializuotų komisijų, sudarytų Stokholmo suvažiavime, pranešimai, kuriuos apsvarsčius nutarta:

- 1929 m. vasara kiek imanoma vienodesniu tikslumu išmatuoti Baltijos trianguliacijos grandineje septynias bazes;

- 1929 m. rudeni nustatyti Konvenciją pasirašiusių šalių centrinių punktų astronominių ilgumu skirtumus Potsdamo observatorijos atžvilgiu;

- 1930 m. Baltijos geodezijos komisijos lěšomis organizuoti dvi ekspedicijas sunkio jègai nustatyti dalyvaujančių šalių centriniuose punktuose.

Rygos suvažiavime, be pranešimų apie geodezinių darbu eigą Konvenciją pasirašiusiose šalyse, buvo išklausytas Norvegijos atstovo pranešimas apie trianguliacijos tinklus, sudaromus topografijos tikslams šioje šalyje nuo $1906 \mathrm{~m}$. [2, 4].

1928 m. rugsëjy Berlyne vyko Baltijos geodezijos komisijos suvažiavimas, kuriame galutinai buvo apibrěžtos numatytų bendrų darbų programos, apimančios trianguliacijos bazių, centrinių punktų astronominių ilgumų ir sunkio jègos matavimus. Konferencijoje konstatuota, kad Konvenciją pasirašiusiose šalyse geodeziniai darbai sparteja. Siekiant patikimiau orientuoti Baltijos trianguliacijos grandinę, nuspręsta sujungti ją su V. Struvès 
trianguliacijos punktais. Todèl nutarta kreiptis $\mathfrak{i}$ atitinkamų šalių vyriausybes raginant surasti bei atnaujinti V. Struvès dienovidinio lanko punktus, juose atlikti astronominius matavimus ir sujungti skersinemis trianguliacijos grandinėmis su Baltijos grandine. Šiuo nutarimu i akciją buvo itrauktos ir toli nuo Baltijos jūros esančios valstybès: Austrija, Vengrija bei Rumunija [2,6].

Penktajame suvažiavime, ivykusiame $1930 \mathrm{~m}$. spaly Kopenhagoje, buvo paskelbta, kad $1929 \mathrm{~m}$. pradžioje, ratifikavusi Baltijos geodezijos konvenciją, Komisijos nare tapo Sovietų Sajunga. Kopenhagos suvažiavime buvo išklausyti specializuotų komisijų pranešimai apie bendrujų darbų, numatytų ankstesniuose suvažiavimuose, eigą. Pranešimuose konstatuota, kad 1929 m. atlikti Baltijos trianguliacijos grandinès bazių matavimai, jų rezultatai paskelbti specialiame Baltijos geodezijos komisijos leidinyje [7]. Tais pačiais metais baigti daugumos šaliu centrinių punktų astronominių ilgumų nustatymo darbai, tačiau nespejus tinkamai irengti punktų, matavimai liko nedaryti Kaune ir Dancige (Gdanske). Neplanuotai nustatyta Pulkovo observatorijos ilguma. Pažymèta, kad 1930 m. Baltijos geodezijos komisijos lěšomis sunkio matavimai atlikti centriniuose punktuose visose dalyvaujančiose šalyse, išskyrus Lenkiją. Suvažiavime išklausyti pranešimai apie geodezinių darbų eigą Baltijos jūros valstybèse. Lietuvai atstovavęs doc. B. Kodatis pranešime pažymèjo, kad Baltijos trianguliacijos grandinès Lietuvos dalyje baigta trianguliacijos punktų statyba. Išmatavus Švėkšnos bazę, pradèta matuoti šios bazès tinklo kampus. 1930 m. Lietuvoje imtasi krašto precizinès niveliacijos. Tais pačiais metais nustatytas Kauno punkto ir Potsdamo observatorijos astronominių ilgumų skirtumas. Isigijus Šterneko svyruoklinị aparatą ir nustačius jo konstantas, pasiruošta gravimetriniams matavimams [8].

Sovietų Sajungai tapus Baltijos geodezijos komisijos nare, kilo drąsus sumanymas sudaryti milžinišką trianguliacijos tinklą nuo rytinių Atlanto krantų per Europą ir Aziją iki Ramiojo vandenyno. Sujungus ši tinklą per Beringo sąsiaurị su numatomais Aliaskos ir esamais Šiaurès Amerikos trianguliacijos tinklais ketinta išmatuoti lygiagretès lanką, apimantị $325^{\circ}$ ilgumos [2, 8].

1932 m. biržely Varšuvoje ivykusiame suvažiavime atstovauta aštuonioms Baltijos geodezinei komisijai priklausančioms šalims. Suvažiavimo darbe nedalyvavo Lietuvos delegacija, negavusi leidimo atvykti i Varšuvą. Šalių atstovų pranešimuose buvo pažymèta, kad tęsiant Baltijos trianguliacijos grandinès matavimus pradèti Vokietijos ir Danijos bei Danijos ir Švedijos trianguliacijų punktų sujungimo darbai. Artimiausiu metu numatyta sujungti Švedijos ir Suomijos trianguliacijų punktus. Pranešta, kad Latvijos teritorijoje rasti keli V. Struvès trianguliacijos punktai, tarp jų - buvusi astronomijos stotis, kurioje $1826 \mathrm{~m}$. daryti astronominiai matavimai. Atnaujinus išlikusi ženklą, ši stotis itraukta i naujaji Latvijos trianguliacijos tinklą.

Suvažiavime perskaitytas pulk. leit. A. Krikščiūno atsiųstas pranešimas apie geodezinių darbų eigą Lietuvoje. Pranešime pažymèta, kad atliekami kampu matavimai Baltijos trianguliacijos grandinès punktuose, išmatuotos Skapiškio ir Kauno bazès, nutiesta $244 \mathrm{~km}$ precizinès niveliacijos linijų, pradèti astronominiai matavimai Laplaso punktuose, vyksta gravimetriniai matavimai. Estijos Generalinio štabo specialistai suvažiavime pateikè magnetometrinès nuotraukos, atliktos $1930 \mathrm{~m}$. ties Lietuvos krantais, rezultatus.

Varšuvos suvažiavime svarstytos precizinès niveliacijos žiedo, kuris juostų Baltijos jūrą, sudarymo galimybès. Nutarta pakartotinai išmatuoti dvi Baltijos trianguliacijos grandinès bazes, kurių viena - Danijoje, Lolando saloje, o antroji Švedijoje, Elando saloje. Kanadai ir JAV nepritarus sumanymui sujungti Europos trianguliacijos tinklus su Amerikos žemyno tinklais, nuspręsta šios idèjos realizavimą atidèti [2, 9].

Septintasis Baltijos geodezijos komisijos suvažiavimas vyko 1934 m. rugsejjy Leningrade ir Maskvoje. Dalyvavo atstovai iš visų devynių šalių Komisijos narių. Aptariant atliktus darbus pažymèta, kad sèkmingai nustatyta visų numatytų astronomijos stočių ilgumų skirtumai. Vertinant sunkio jègos matavimo rezultatus konstatuota, kad dvieju 1930 m. organizuotu ekspedicijų gautieji rezultatai nesutapo. Skirtumai siekè iki $7 \mathrm{mGal}$ [2]. Nuspręsta sunkio pagreičio matavimus kartoti Potsdame ir Kopenhagoje.

Suvažiavime išreikštas pageidavimas sujungti Sovietų Sajungos trianguliacijos tinklus su Suomijos, Estijos ir Lenkijos tinklais. Pritarta minčiai sudaryti precizinès niveliacijos žiedą, kuris juostų Baltijos jūrą. Artejjant Baltijos geodezijos konvencijos galiojimo pabaigai, numatytai 1936 m., atsižvelgiant, kad iki tol nebus baigtas Baltijos trianguliacijos grandinès išlyginimas, ir vos tik pradèti bendri precizinès niveliacijos darbai, svarstytas Konvencijos sutarties pratęsimo klausimas [10].

Remiantis 1934 m. suvažiavimo nutarimais, Baltijos geodezijos komisijos prezidentas nedelsdamas iteike Suomijos užsienio reikalų ministerijai oficialų raštą dèl Konvencijos atnaujinimo, prašydamas perduoti ji Konvenciją pasirašiusių šalių vyriausybėms. Rašte išvardyti baigtieji bei baigiami bendrieji darbai ir nurodyti naujai kilę uždaviniai, kuriems spręsti būtina pratęsti Konvencijos galiojimą mažiausiai dar dvylikai metų [11].

1935 m. rugpjūty Taline ir Tartu vyko aštuntasis Baltijos geodezijos komisijos suvažiavimas. Atstovauta visoms devynioms šalims Komisijos narėms. Be to, suvažiavime dalyvavo Tarptautinès geodezininkų asociacijos generalinis sekretorius bei keli ižymūs geodezininkai iš Didžiosios Britanijos ir Norvegijos.

Suvažiavime buvo nagrinèti Baltijos trianguliacijos grandinès išlyginimo principai ir precizinès niveliacijos žiedo apie Baltijos jūrą sudarymo klausimai. Rengiantis išlyginti Baltijos trianguliacijos grandinę, numatyta išsamiai išnagrinèti išlyginimo klausimus ir susitarti dèl pagrindinių nuostatų. Išklausyti pranešimai apie geodezinių darbų eigą visose atstovaujamose šalyse. Lietuvos atstovo doc. B. Kodačio pranešime pažymèta, jog šalyje išmatuota 
46 pirmosios eilès trianguliacijos trikampiu kampai. I naujaji trianguliacijos tinklą Rytų Lietuvoje ittraukti aštuoni K. Tenerio trianguliacijos punktai. Tarp jų keturių punktų - KINDERIAI, MARTINČIŪNAI, AMBRAZIŠKIAI ir KONGEDAI - surasti senieji centrai. Nutiesta $839 \mathrm{~km}$ precizinès niveliacijos linijų. Baigti astronominiai matavimai aštuoniuose Baltijos trianguliacijos grandinès punktuose bei visi numatytieji gravimetriniai matavimai [11].

Devintasis Baltijos geodezijos komisijos suvažiavimas vyko 1936 m. liepa Helsinkyje. Šiame suvažiavime buvo atstovaujamos visos Komisijos narès, išskyrus Lenkiją ir Laisvaji Dancigo miestą. Suvažiavimo darbe dalyvavo Tarptautinès geodezininkų asociacijos prezidentas ir svečiai iš Didžiosios Britanijos. Delegacijų pranešimuose pažymèta, jog daugelyje šalių Baltijos trianguliacijos grandinès matavimai baigti. Liko neišmatuotas grandinès ruožas šiaurinejje Vokietijos dalyje, ji baigti numatyta $1938 \mathrm{~m}$. Švedijoje baigiama matuoti trianguliacijos kampus, tačiau dar nepradèti gravimetriniai matavimai. Latvijoje permatuoti Liepojos bazès tinklo kampai. Jais remiantis perskaičiuotos apie $27 \mathrm{~km}$ pradinès kraštinès ilgis pakito 12,5 cm. Suomijoje, sudarant 1:20 000 mastelio pagrindini krašto topografini žemèlapi, nuo $1935 \mathrm{~m}$. pradèta naudoti aeronuotrauką. Lietuvai atstovavusio doc. B. Kodačio pranešime pažymèta, kad baigus matavimus Baltijos trianguliacijos grandinès Lietuvos dalyje, vyksta trianguliacijos darbai ir astronominiai matavimai šiauriniame šalies pakraštyje. Tęsiama precizinè niveliacija.

1936 m. suvažiavime galutinai susitarta dèl Baltijos trianguliacijos grandinès išlyginimo principų, kuriais remiantis visa grandinè padalyta i sekcijas, parenkant jų sąsajų punktus kuo arčiau išmatuotų bazių. Kiekvienai atstovaujamai šaliai buvo pasiūlyta atskirai išlyginti jai priklausančia sesija, remiantis tarptautiniu (Madrido) elipsoidu. Išlygintas sekcijas pakeitus geodezinèmis linijomis, jungiančiomis sekcijų sąsaju punktus, numatyta sudaryti uždarą poligoną, o pastaraji išlyginus gauti geodezinių linijų ilgių ir jų sudaromu kampu patikimiausias pataisas. Baltijos geodezijos komisijos biudžete numatyta lèšų bendram trianguliacijos grandinès išlyginimui [12].

Sudaromos Baltijos trianguliacijos grandinès schema su pažymėtais sekcijų punktais, pateikta 1 pav. Lietuva buvo ipareigota išlyginti vakariniu šalies pakraščiu nutiestą grandinès sekciją, jungiančią gretimus ryšio punktus 8 (AKMENIŠKIAI) ir 7 (ARAJS). Lyginti sekcija buvo pradèta 1939 m., tačiau ši darbą nutraukè sovietu okupacija. Vèliau Lietuvos sekcija buvo išlyginta Suomijos Geodezijos institute.

Suvažiavime nutarta paskelbti Baltijos jūrą ir Botnijos bei Suomijos ilankas juosiančio precizinès niveliacijos žiedo, susidedančio iš esamų ir projektuojamų elementų, schemą, kurioje būtų pažymeti mareografai ir futštokai ( 2 pav.).

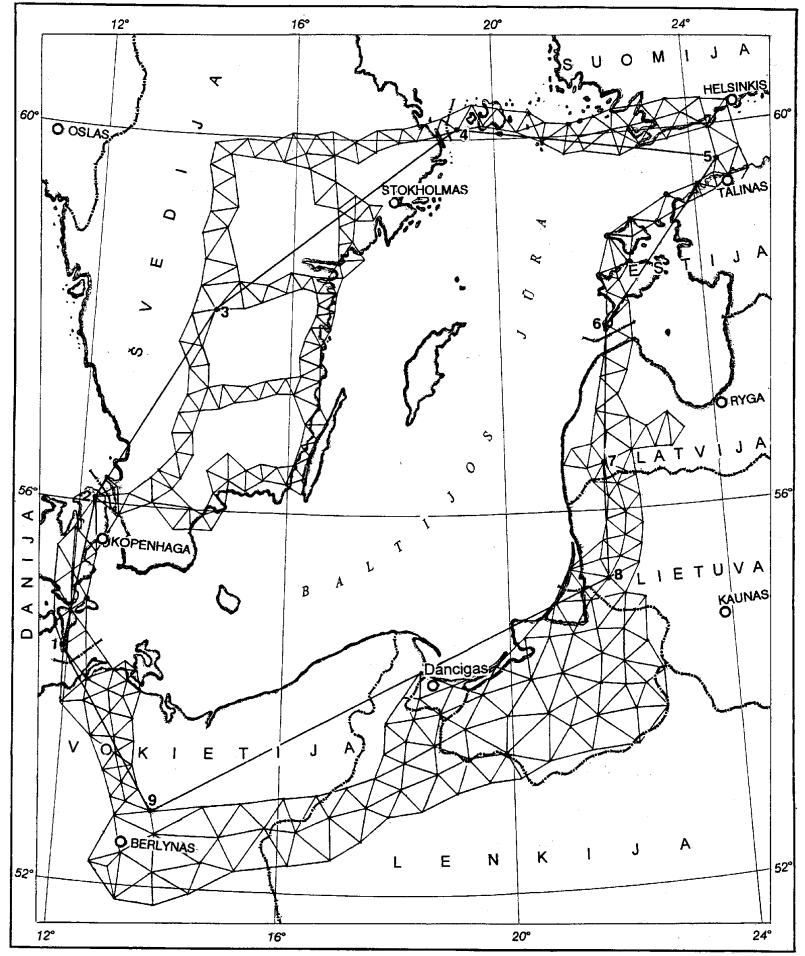

1 pav. Baltijos trianguliacijos grandinè

Fig 1. Baltic Triangulation Chain

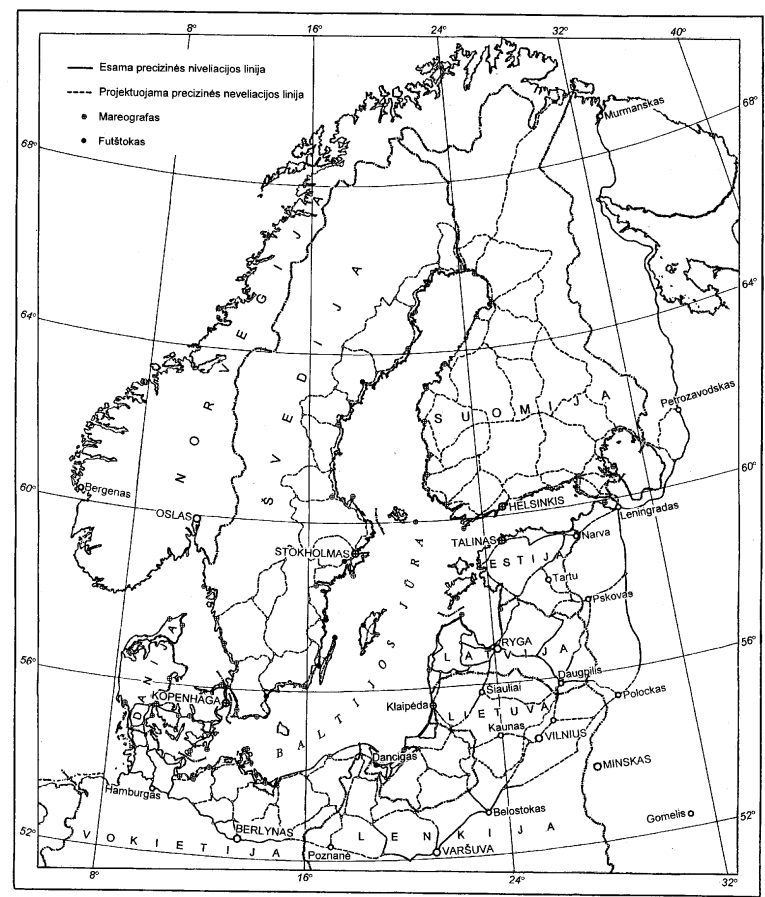

2 pav. Baltijos jūrą ir Botnijos bei Suomijos illankas juosiančio precizinès niveliacijos žiedo projektas

Fig 2. Project of precise levelling around the Baltic Sea, Gulf of Botnia and Gulf of Finland

Schemoje numatyta Lietuvos precizinès niveliacijos tinklą sujungti su Latvijos tinklu ties Skuodu, ties valstybès siena tarp Joniškio ir Jelgavos bei tarp Obelių ir Daugpilio; 
su Vokietijos niveliacijos tinklu ties Tilže ir ties Eitkūnais, o su lenkų okupuoto Vilniaus krašto tinklu ties Lentvariu [12].

Helsinkio suvažiavime priimtas protokolas, kuriame pažymèta, kad $1935 \mathrm{~m}$. pabaigoje per Suomijos užsienio reikalų ministeriją buvo perduotas Baltijos geodezijos komisijos prezidento raštas visoms šalims Komisijos narėms dèl Konvencijos sutarties pratęsimo. I šį raštą gauti teigiami visų Komisijos narių atsakymai. Protokole nurodyta, kad sutartis isigalios visoms dalyvaujančioms šalims pateikus šio protokolo ratifikavimo raštus.

Paskutinis - dešimtasis Baltijos geodezijos komisijos suvažiavimas vyko 1938 m. biržely Kaune. Buvo aštuonių šalių atstovai: Danijos, Estijos, Latvijos, Lenkijos, Lietuvos, Suomijos, Švedijos ir Vokietijos. Be to, suvažiavimo darbe dalyvavo Tarptautinès geodezininku asociacijos prezidentas ir geodezijos specialistai iš Norvegijos bei Didžiosios Britanijos. Suvažiavime nebuvo delegacijos iš Sovietų Sajungos, kuri 1938 m. kovą savo noru išstojo iš Baltijos geodezinès komisijos. Pradedant suvažiavimą paskelbta, kad deponavus Suomijos užsienio reikalų ministerijoje visų atstovaujamų šalių ratifikavimo raštus, $1937 \mathrm{~m}$. sausio 20 d. isigaliojo Baltijos geodezijos konvencija naujam 12 metu periodui, kurio trukmé - iki 1948 m. pabaigos.

Atstovaujamu šalių pranešimuose pažymèta, kad baigiami Baltijos trianguliacijos grandinès matavimai. Dar neišmatuotas Vokietijos trianguliacijos šiaurinis ruožas, besiribojantis su Danijos trianguliacijos grandine, ir tebematuojami trikampiai, jungiantys Švedijos ir Suomijos tinklus. Suomijos Geodezijos instituto išlygintas Baltijos trianguliacijos grandinès Estijos ruožas suvažiavime pristatytas kaip grandinès dalinio išlyginimo pavyzdys. Vokietijoje išlygintas Rytų Prūsijos trianguliacijos tinklas, besiribojantis su Lietuvos tinklu. Lietuvos ir Latvijos teritorijomis nutiestų grandinès ruožų išlyginimas dar nepradètas neturint galutinių Laplaso punktuose darytų astronominių matavimų rezultatų.

Svarstant precizinès niveliacijos Baltijos žiedo sudarymą konstatuota, kad visose dalyvaujančiose šalyse, išskyrus Švediją, vyksta niveliavimo darbai. Suomijos pietvakarineje dalyje atliktos niveliacijos rezultatai parodė gana spartų Žemès paviršiaus kilimą, kurio greitis šiauriau Turku miesto siekiantis $6 \mathrm{~mm} / \mathrm{m}$. Danijoje vyksta hidrostatinis niveliavimas $18 \mathrm{~km}$ atstumu tarp Didžiojo Belto sąsiaurio krantų. Vokietijoje ištirtos trigonometrinio niveliavimo per jūros sąsiauri galimybès. Lenkijoje $1937 \mathrm{~m}$. baigtas sudaryti pirmosios eilès krašto niveliacijos tinklas iš 36 uždarų poligonų. Jo perimetras - apie $10000 \mathrm{~km}$. 4 poligonų linijos nutiestos dabartine Lietuvos teritorija. Vokietijos ir Danijos specialistai pradèjo gravimetrinius matavimus Baltijos jūros akvatorijoje.

Suvažiavime išklausytas pulk. A. Krikščiūno pranešimas, kuriame pažymèta, kad Lietuvos teritorijoje išmatuoti 73 pirmosios eilès trianguliacijos trikampiai, neskaičiuojant trijų bazių tinklų. Ateityje numatyta išmatuoti dar dvi bazes - prie Šiaulių ir Lazdijų. Tikrinant išlyginto Švejkšnos bazès tinklo pradinès kraštinès ilgi, ši kraštinè apskaičiuota pagal trikampius, remiantis Skapiškio baze ir Rytų Prūsijos bei Latvijos trianguliacijų kraštinėmis. Rezultatų nesutapimai siekè nuo 3 iki $24 \mathrm{~cm}$. Labai didelis $(7,64 \mathrm{~m})$ nesutapimas gautas skaičiuojant nuo Rytų Prūsijos trianguliacijos kraštinès AKMENIŠKIAIVINGKAPIS. Išsiaiškinus šio nesutapimo priežasti, nustatytas punkto VINGKAPIS, ittvirtinto Kuršių nerijos smėlio kopoje, viršutinio centro poslinkis. Pažymèta, kad Lietuvoje nutiesta $1575 \mathrm{~km}$ precizinès niveliacijos linijų, sudarančiu penkis uždarus poligonus, kuriuose didžiausias aukščiu nesąryšis siekia $12,9 \mathrm{~mm}$. Lietuvos precizinès niveliacijos tinklas sujungtas su atitinkamais Latvijos ir Vokietijos tinklais. Tęsiami magnetometriniai matavimai, nustatant magnetines charakteristikas vietovès taškuose kas $20 \mathrm{~km}$.

Kaune ivykusiame suvažiavime nutarta sudaryti ir išleisti geodezinių koordinačių, perskaičiuotų pagal Tarptautinio elipsoido parametrus, lenteles, apimančias iki $35^{\circ}$ šiaurès platumos. Pagal šio elipsoido parametrus numatyta apskaičiuoti Baltijos trianguliacijos grandinès punktų koordinates [13]. Kitą Baltijos geodezijos komisijos suvažiavimą ketinta sušaukti $1940 \mathrm{~m}$. Berlyne, tačiau prasidèjus karui daugiau suvažiavimų nevyko. Karo pradžioje dar vyko Komisijos prezidiumo posėdžiai 1940 m. rugsèjy - Stokholme ir 1941 m. lapkrity - Kopenhagoje [14]. Kai kurie bendrieji Komisijos darbai buvo tęsiami Suomijos Geodezijos institute.

Baltijos geodezijos komisija tarpukario metais organizavo pagrindinius geodezinius darbus Baltijos jūrą supančiose šalyse, tarp jų ir Lietuvoje. Komisijos pastangomis atliekant matavimus buvo laikomasi vienodos metodikos ir tikslumo normų, taikomi naujausi mokslo ir technikos laimèjimai. Komisijos rengiamuose suvažiavimuose buvo išklausoma visų atstovaujamų šalių pranešimų apie jose atliekamu geodezinių darbu eigą. Tai skatino šalis laikytis isipareigojimų. Būdinga, kad Lietuva, viena iš paskutiniuju pradèjusi Baltijos trianguliacijos grandinès matavimus, baigé savo lauko darbų programą $1935 \mathrm{~m}$., drauge su Suomija ir Danija, aplenkdama daugeli šalių, turinčių senas matavimų tradicijas.

Po kiekvieno Baltijos geodezinès komisijos suvažiavimo buvo spausdinami skaitytų pranešimu ir nutarimu rinkiniai. Baigus bendruosius matavimus, sudaryti ir išleisti specialūs leidiniai su bazių matavimo ir centrinių punktų astronominių ilgumų bei sunkio pagreičio nustatymo rezultatais. Reikšminga veikla Baltijos geodezijos komisijos darbe pasižymejjo prof. T. I. Bonsdorfas, šios Komisijos ikūrèjas, ilgametis generalinis sekretorius ir daugelio leidinių sudarytojas bei leidejas. Ivertinus profesoriaus nuopelnus organizuojant bei koordinuojant geodezinius darbus, atliekamus Lietuvoje ir kitose Baltijos jūros šalyse, Vytauto Didžiojo universiteto Technikos fakulteto taryba 19341114 jam suteikè garbès daktaro vardą [15]. Prof. T. I. Bonsdorfo nuopelnus mokslui ir mūsų kraštui pripažino ir Lietuvos Vyriausybè - apdovanojo Gedimino ordinu [16]. 


\section{Išvados}

Prieš aštuonis dešimtmečius ikurtoji Baltijos Geodezinė komisija atliko lemiamą vaidmeni organizuojant tarpukario metais pagrindinius geodezinius darbus Baltijos jūrą supančiose šalyse, tarp jų ir Lietuvoje.

Baltijos geodezijos komisijos pastangomis, dalyvaujant aštuonioms valstybėms, tarpukariu buvo išmatuota trianguliacijos grandinè, juosianti Baltijos jūrą. Matavimų rezultatai neprarado aktualumo iki XX a. pabaigos. Lietuvos teritorijoje dideliu tikslumu išmatuota viena Baltijos trianguliacijos grandinès bazių - Švėkšnos bazè, jungianti Rytų Prūsijos ir Latvijos trianguliacijos tinklus.

Baltijos geodezijos komisijos veiklą nutraukè Antrasis pasaulinis karas.

\section{Literatūra}

1. Comptes rendus des séances de la conférence géodésique réunie à Helsingfors du 28 juin au 2 juillet 1924. - Verhandlungen der in Helsingfors vom 28. Juni bis 2. Juli 1924 abgehaltenen geodätischen Konferenz. Helsinki, 1925. $150 \mathrm{~S}$.

2. Bonsdorff, I. Establishment of Baltic Geodetic Commission it's goals and atchieved results. (Prof. S. Dirmantas translation to Lithuanian) Technika, No 8, 1936, p. 195-204 (in Lithuanian).

3. Comptes rendus de la deuxième séance de la Commission Géodésique Baltique réunie à Stockholm du 10 au 14 août 1926. - Verhandlungen der in Stockholm vom 10. bis 14. August 1926 abgehaltenen zweiten Tagung der Baltischen Geodätischen Kommission. Helsinki, 1927.96 S.

4. Comptes rendus de la troisième séance de la Commission Géodésique Baltique réunie à Riga du 20 au 23 mai 1927. - Verhandlungen der in Riga vom 20. bis 23. Mai 1927 abgehaltenen dritten Tagung der Baltischen Geodatischen Kommission. Helsinki, 1928.

5. Kolupaila, S. Baltic Geodetic Commission. Matininkas, No 2-3, 1926, p. 7-11 (in Lithuanian).

6. Comptes rendus de la quatrième seance de la Commission Géodésique Baltique réunie à Berlin du 24 au 28 september 1928. - Verhandlungen der in Berlin vom 24. bis 28. September 1928 abgehaltenen vierten Tagung der Baltischen Geodätischen Kommission. Helsinki, 1929. 164 S.
7. Special Publikation No.1: Measuring of Seven Base Lines of the Baltic Polygon Executed in the Year 1929, by Ilmari Bonsdorff. Helsinki, 1930. 241 p.

8. Comptes rendus de la cinquième séance de la Commission Géodésique Baltique réunie à Copenhague du 13. au 18. octobre 1930. - Verhandlungen der in Kopenhagen vom 13 bis 18. October 1930 abgehaltenen fünften Tagung der Baltischen Geodätischen Kommission. Helsinki, 1931. $275 \mathrm{~S}$.

9. Comptes rendus de la sixsieme seance de la Commission Géodésique Baltique réunie a Varsovie du 14 au 18 juin 1932. - Verhandlungen der in Warschau vom 14. bis 18. Juni 1932 abgehaltenen sechsten Tagung der Baltischen Geodätischen Kommission. Helsinki, 1933. 226 S.

10. Comptes rendus de la septième séance de la Commission Géodésique Baltique réunie à Leningrad et Moscou 12 au 19 septembre 1934. Ie partie: Proces - verbaux et rapports. Verhandlungen der in Leningrad und Moskau vom 12. bis 19. September 1934 abgehalten siebenten Tagung der Baltischen Geodätischen Kommission. I Teil: Protokole und Berichte. Helsinki, 1935. 182 S.

11. Comptes rendus de la huitième session de la Commission Géodésique Baltique réunie á Tallinn et Tartu du 20 au 23 août 1935. - Verhandlungen der in Tallinn und Tartu vom 20. bis 23. August 1935 abgehaltenen achten Tagung der Baltischen Geodätischen Kommission. Helsinki, 1936. $296 \mathrm{~S}$.

12. Comptes rendus de la neuvième session de la Commission Géodésique Baltique réunie à Helsinki du 21 au 25 jullet 1936. - Verhandlungen der in Helsinki vom 21. bis 25. Juli 1936 abgehaltenen neunten Tagung der Baltischen Geodätischen Kommission. Helsinki, 1937. 284 S.

13. Comptes rendus de la dixième session de la Commission Géodésique Baltique réunie à Kaunas du 14 au 17 juin 1938. - Verhandlungen der in Kaunas vom 14. bis 17. Juni 1938 abgehaltenen zehnten Tagung der Baltischen Geodätischen Kommission. Helsinki, 1938. $141 \mathrm{~S}$.

14. L'activité de la Commission Géodésique Baltique pendant les annés 1938 - 1941. - Die Tätigkeit der Baltischen Geodätischen Kommission in den Jahren 1938 - 1941. Helsinki, 1942.

15. Kolupaila, S. Professor Toivo Ilmari Bonsdorff Honoris Causa Doctor and Engineer of Vytautas Magnus University. Kosmos, XVI, No 1-3, 1935, p. 1-3 (in Lithuanian).

16. Dirmantas, S. Professor Toivo Ilmari Bonsdorff' Honoris Causa Doctor of Vytautas Magnus University. Technika, No 8, 1935, p. 187-194 (in Lithuanian). 